\title{
The effect of cimaterol and oestradiol-17 $\beta$, given alone or combined, on ovine lipid metabolism, plasma metabolites and tissue cyclic AMP concentrations
}

\author{
JR Scaife, EM Alderson, $\mathrm{H}$ Galbraith \\ Department of Agriculture, University of Aberdeen, 581 King Street, Aberdeen AB9 1UD, UK
}

(Received 29 January 1993; accepted 19 April 1993)

\begin{abstract}
Summary - The effect of cimaterol (2 mg/kg dry matter in the diet) and oestradiol-17及 (OE, $15 \mathrm{mg}$ implanted sc) given alone or combined for 62 or $63 \mathrm{~d}$ was studied in 24 male castrate sheep. Neither cimaterol nor $O E$ treatment in vivo affected indices of lipid metabolism. However, in vitro studies suggested that added cimaterol: a) had little effect on lipogenesis; and b) increased lipolysis in subcutaneous adipose tissue (SCAT) at least as effectively as epinephrine. Plasma urea concentrations were reduced on $d 7,14$ and 21 by cimaterol and on $d 28$ and 42 by OE. Plasma NEFA was reduced by $\mathrm{OE}$ treatment on $\mathrm{d} 7$. Serum triacylglycerol concentrations were not affected by the treatment. Cimaterol reduced cyclic AMP concentrations in skeletal muscle (m gluteus) preparations. Treatment with OE reduced lipoprotein lipase activity of SCAT.
\end{abstract}

cimaterol / oestradiol-17 / lipogenesis / lipolysis / cyclic AMP

Résumé - Effet du cimatérol et de l'oestradiol-17 $\beta$ administrés seuls ou de façon combinée sur le métabolisme des lipides des ovins, les métabolites plasmatiques et les concentrés AMP cycliques des tissus. Les effets sur le métabolisme lipidique et la concentration de cAMP dans les tissus d'un traitement avec cimatérol (2 mg/kg matière sèche dans l'aliment) et cestradiol$17 \beta$ (OE, $15 \mathrm{mg}$ implanté en sous-cutané) seul ou ensemble pendant 62 ou 63 jours, ont été étudiés dans 24 Finn x Dorset béliers castrés. Les vitesses de lipogenèse et de lipolyse ont éré mesurées in vitro dans le tissu adipeux sous-cutané (SCAT) immédiatement après abattage, avec ou sans addition de cimatérol $(0,15$ et 1,5 $\mu \mathrm{mol} / \mathrm{l})$. II n'a pas été trouvé de différences significatives dans les vitesses moyennes de lipogenèse in vitro entre les groupes. La vitesse moyenne de lipogenèse a eu tendance à diminuer avec l'augmentation de la concentration de cimatérol dans le milieu de couvraison (tableau I). II n'y a pas eu de résultats significatifs des traitements sur la vitesse de base ni sur la vitesse stimulée sans addition de cimatérol. L'addition de cimatérol a augmenté significativement la vitesse de base de lipogenèse mais n'a pas changé la vitesse de lipogenèse stimulée par épinéphrine. La réponse de la vitesse de base de lipogenèse à l'addition de cimatérol $(0,15 \mu$ mol/l) a été significativement réduite dans les animaux traités avec cimatérol (tableau II). Les concentrations de cAMP, dans l'ordre foie > muscle > (SCAT), ont été significativement plus basses dans le muscle des animaux traités avec du cimatérol (tableau IIIa). L'activité de lipoprotéine lipase en SCAT a été 
significativement réduite par le traitement avec OE (tableau IIIb). Les concentrations d'urée dans la plasmatique ont été réduites par cimatérol après 7,14 et 21 jours et par OE après 28 et 42 jours. NEFA dans le plasma a été réduit par le traitement avec OE sur jour 7 . Les concentrations de triacylglycérol n'ont pas changé selon le traitement (fig 1). Les données suggèrent que les effets in vitro de l'addition de cimatérol au milieu de couvraison sur la lipogenèse et la lipolyse dans les tissus adipeux d'ovins sont semblables aux autres substances $\beta$-adrénergiques. Les effets de traitement in vivo ne sont pas liés aux changements en lipogenèse et lipolyse mesurées in vitro et ne sont pas clairs.

cimatérol / astradiol-17 / lipogenèse / lipolyse / AMP cycliques

\section{INTRODUCTION}

The effects of oestrogenic or androgenic steroidal compounds in promoting growth and altering body composition in farm and laboratory animals has been well demonstrated (Galbraith and Topps, 1981). More recently there has been increasing interest in the effects of $\beta$-adrenergic sympathomimetic compounds (" $\beta$-agonists") in a number of species (Reeds and Mersmann, 1991).

Beta-agonists such as isoproterenol, salbutamol, racropamine, L-640-033 and BRL35135 are structural analogues of the catecholamines. A number of these synthetic compounds have shown considerable potential in the improvement of the growth performance and carcass characteristics of farm animals (Muir, 1988). Two such compounds, clenbuterol (5-[1hydroxy-2(isopropyl-amino)ethyl]anthranilonitrile) and cimaterol (4-amino-[t-butyl amino methyl]-3,5-dichlorobenzyl alcohol) are orally active and have been shown to increase skeletal muscle accretion and reduce fat deposition in a number of species (Reeds and Mersmann, 1991).

The degree of similarity of the effects of anabolic steroids and those of $\beta$-agonists in altering body composition within animals is not clear and requires elucidation. It is possible that $\beta$-agonists act via adrenoreceptors and second messenger cyclic AMP (cAMP) production in fat depots and skeletal muscle tissue of animals, although this question has not yet been resolved (Reeds and Mersmann, 1991). Oestradiol$17 \beta$ (OE) may act by altering responsiveness to somatotrophin (Buttery and Dawson, 1987). The objective of this experiment was to examine the effects of cimaterol given alone or in combination to castrate male sheep on lipogenesis and lipolysis in vitro in subcutaneous adipose tissue (SCAT), on lipoprotein lipase activity and on concentrations of CAMP in a variety of tissues. The effects of treatments on growth performance and body composition of sheep have been presented elsewhere (Galbraith et al, 1990). Briefly, both cimaterol and $O E$ increased growth rate and protein deposited in the carcass, but cimaterol alone significantly reduced carcass fat accretion.

\section{MATERIALS AND METHODS}

A detailed description of animal selection, nutrition and experimental treatments has been given elsewhere (Galbraith et al, 1990). In summary, 24 Finn $x$ Dorset male castrate sheep weighing on average $18.0 \mathrm{~kg}$ and aged $\approx 10 \mathrm{wk}$ were offered a good quality diet to provide intakes of $38 \mathrm{~g} / \mathrm{kg}$ live weight.

The sheep were blocked by weight into 6 blocks of 4 animals and randomly allocated to untreated controls (group U), implanted with $15 \mathrm{mg}$ OE (one-third of the Compudose-365 implant ("Elanco Products Ltd") (group OE), which received cimaterol in the diet (Boehringer Ingleheim Vetmedica $\mathrm{GmBh}$ ) (group C) or were implanted with $15 \mathrm{mg} \mathrm{OE}$ and received cimaterol in the diet (group $\mathrm{OE}+\mathrm{C}$ ). The concentration of 
cimaterol in the diet was $2 \mathrm{mg} / \mathrm{kg}$. To facilitate the processing of post-mortem samples, animals were implanted over a 2-d period and were slaughtered unfasted in blocks after 62 or $63 d$ over a period of $4 \mathrm{~d}$.

Samples of liver, muscle (m gluteus) and SCAT were taken immediately post-mortem, frozen in liquid nitrogen and thereafter stored at $-60^{\circ} \mathrm{C}$ prior to analysis. Measurement of the CAMP content of muscle, liver and SCAT was carried out by radioimmunoassay (Du Pont UK Ltd, Kit No NEK-033). Lipoprotein lipase (LPL) was prepared from SCAT as described by Rao and Hawkins (1976), and assayed using the incubation conditions described by Krauss et al (1973) and the fatty acids extracted by the procedure of Schotz et al (1970).

For practical reasons, comparison of lipogenic and lipolytic activity was made on the basis of wet weight of tissue rather than on an equivalence of cell numbers. Hu et al (1988) and Coleman et al (1988) have reported recently that adipocyte number per $\mathrm{g}$ of tissue was not altered in cimaterol-fed sheep, suggesting that satisfactory comparison of treatment effects may be made on a weight basis. Accordingly small pieces $(\approx 30 \mathrm{~g})$ of SCAT, used for the measurement of the in vitro rates of lipogenesis and lipolysis, were taken immediately postmortem and transferred to physiological saline at $39^{\circ} \mathrm{C}$. The rate of lipolysis (both basal and epinephrine-stimulated), and lipogenesis measured as described by Pothoven and Beitz (1973) and Pothoven et al (1975) respectively, was estimated in triplicate in the absence and in the presence of cimaterol added to the incubation medium to give a final concentration of 0.15 or $1.5 \mu \mathrm{mol} / \mathrm{l}$.
Weekly blood samples $(20 \mathrm{ml})$ were collected prior to morning feeding by jugular venipuncture for the preparation of plasma and serum. Samples of plasma were analysed for urea by the method of Marsh et al (1965) and non-esterified fatty acids (NEFA) by the method of Baird et al (1967) after extraction as described by Trout et al (1960). Serum samples were analysed for triglycerides (TG) by the Boehringer test combination kit (Boehringer Mannheim).

All data were analysed by analysis of variance using GENSTAT $V$ (Lawes Agricultural Trust, 1977). There was no evidence of any influence of blocking on the analysis; thus the data used are unadjusted for missing values. Data for plasma NEFA and triglycerides were analysed using the mean value for samples taken on $d O$ as covariate. Data for lipogenesis and lipolysis were analysed by split-plot ANOVA. In the analysis of variance the sum of squares of the treatments was partitioned into 3 orthogonal parts, each with one degree of freedom corresponding to the main effects of $O E$, cimaterol and the interaction between $O E$ and cimaterol.

\section{RESULTS}

In vitro rates of lipogenesis determined by the incorporation of $\left[{ }^{14} \mathrm{C}\right]$-acetate into preparations of SCAT are shown in table I. In the absence of added cimaterol there was no effect of in vivo treatment with dietary cimaterol or OE implants on the rates of lipogenesis. Nor were there any significant effects of in vivo treatment of the animals

Table I. Rate of lipogenesis in SCAT in the presence or absence of cimaterol added to the incubation medium ( $\mu \mathrm{mol}$ acetate incorporated/g tissue/h).

\begin{tabular}{lllllll}
\hline $\begin{array}{l}\text { Cimaterol } \\
(\mu \text { mol/ } /)\end{array}$ & \multicolumn{5}{c}{ Treatment groups } & \multirow{2}{*}{$\begin{array}{l}\text { Overall } \\
\text { means }\end{array}$} \\
\cline { 2 - 5 } & $U$ & $O E$ & $C$ & $O E+C$ & $S E D$ & \\
\hline & & & & & & \\
0 & 5.3 & 5.5 & 6.7 & 4.8 & 1.19 & 5.6 \\
0.15 & $4.1^{\mathrm{a}}$ & $5.3^{\mathrm{a}}$ & $4.5^{\mathrm{a}}$ & $6.9^{\mathrm{b}}$ & 1.19 & 5.2 \\
1.5 & 4.2 & 5.2 & 4.0 & 4.2 & 1.30 & 4.4 \\
\hline
\end{tabular}

SED for comparison of any 2 means in the same column $=1.84(38 \mathrm{df}) ;$ SED for overall means $=0.92$; Treatment means in the same row with dissimilar superscripts are significantly different $(P<0.05)$. 
on the response of SCAT to the addition of cimaterol to the incubation medium except in the presence of $0.15 \mu \mathrm{mol} / \mathrm{l}$ added cimaterol when the rate of lipogenesis in treatment $O E+C$ was significantly greater $(P<0.05)$ than that in treatment U. However, comparison of orthogonal contrasts, comparing the effects of the presence versus the absence of the œstradiol- $17 \beta$ or cimaterol, indicated no significant effect of either cimaterol of oestradiol-17 $\beta$ on lipogenesis in vitro. Although overall treatment means decreased with increasing concentration of added cimaterol, these differences were not significant.

In the absence of cimaterol added to the incubation medium there was no significant effect of in vivo treatment of sheep with cimaterol and/or OE on the basal or epinephrine-stimulated rates of lipolysis (table II). Comparison of the overall treatment group means showed that, as expected, epinephrine significantly increased the rate of lipolysis from that shown for basal incubations with no added cimaterol. Added cimaterol also significantly in- creased the overall basal rate of lipolysis in a dose-dependent fashion (table lla) but had no effect on the overall rates of epinephrine-stimulated lipolysis (table $\mathrm{llb}$ ). Comparison of orthogonal contrasts indicated that the basal lipolytic response to a cimaterol concentration of $0.15 \mu \mathrm{mol} / \mathrm{l}$ was significantly less $(P<0.05)$ in cimateroltreated animals (groups $\mathrm{C}$ and $\mathrm{OE}+\mathrm{C}$ ) than in those which received no cimaterol in the diet (groups $U$ and $O E$ ).

Cyclic AMP concentrations (table Illa) were greatest in liver and lowest in SCAT. In these tissues treatment of sheep with cimaterol with or without $\mathrm{OE}$ or $\mathrm{OE}$ given alone had no significant effect upon CAMP concentrations. However, orthogonal contrasts indicated that in the skeletal muscle preparation CAMP concentrations were significantly lower $(P<0.05)$ in cimateroltreated animals (groups $\mathrm{C}$ and $\mathrm{OE}+\mathrm{C}$ ).

Lipoprotein lipase activity in SCAT (table $\mathrm{lllb}$ ) was significantly lower $(P<$ 0.01 ) in OE-treated animals (groups $O E$ and $O E+C$ ) than in those animals not giv-

Table II. Effect of cimaterol on (a) basal and (b) epinephrine $(2.7 \mu \mathrm{mol} / \mathrm{l})$ stimulated rates on lipolysis in subcutaneous adipose tissue ( $\mu \mathrm{mol}$ glycerol released $/ \mathrm{g} / \mathrm{tissue} / \mathrm{h}$ ).

\begin{tabular}{|c|c|c|c|c|c|c|}
\hline \multirow{2}{*}{$\begin{array}{l}\text { Cimaterol } \\
(\mu \mathrm{mol} / 1)\end{array}$} & \multicolumn{5}{|c|}{ Treatment groups } & \multirow{2}{*}{$\begin{array}{l}\text { Overall } \\
\text { means }\end{array}$} \\
\hline & $U$ & $O E$ & $C$ & $O E+C$ & SED & \\
\hline
\end{tabular}

$\begin{array}{lrrrrrr}\begin{array}{l}\text { (a) } \\ 0\end{array} & 330 & 363 & 414 & 370 & 103.5 & 370^{\mathrm{a}} \\ 0.15 & 1738 & 1698 & 1267^{*} & 1224^{*} & 375.9 & 1484^{\mathrm{b}} \\ 1.5 & 1822 & 1767 & 2007 & 1850 & 308.9 & 1866^{\mathrm{c}} \\ & & & & & & \\ \text { (b) } & 1611 & 1406 & 1402 & 1149 & 267.1 & 1402^{\mathrm{b}} \\ 0 & 1525 & 1213 & 1558 & 1172 & 288.8 & 1383^{\mathrm{b}} \\ 0.15 & 1370 & 1070 & 1272 & 1132 & 238.4 & 1221^{\mathrm{b}} \\ 1.5 & & & \end{array}$

SED for comparison of any 2 means in the same column $=199(92 \mathrm{df})$; SED for overall means $=99.6$; overall means with dissimilar superscripts are significantly different $(P<0.001)$; * Main effect of cimaterol $(P<0.05)$. 
Table III. Concentration of cAMP in subcutaneous adipose tissue, liver and skeletal muscle samples (nmoles/g) (a); and lipoprotein lipase activity in subcutaneous adipose tissue ( $\mu \mathrm{mol}$ fatty acid relea$\mathrm{sed} / \mathrm{g}$ tissue/h) (b).

\section{Cimaterol $(\mu \mathrm{mol} / \mathrm{l})$}

Treatment groups

\begin{tabular}{lllll}
\hline$U$ & $O E$ & $C$ & $O E+C$ & $S E D$
\end{tabular}

(a)

\begin{tabular}{llllll} 
Adipose tissue & 0.16 & 0.27 & 0.20 & 0.20 & 0.027 \\
Liver & 2.24 & 2.08 & 2.04 & 1.85 & 0.326 \\
Muscle & 1.00 & 1.03 & $0.74^{*}$ & $0.78^{\star}$ & 0.131 \\
& & & & & \\
(b) & & & & & \\
Adipose tissue & 12.4 & $6.07^{* *}$ & 13.6 & $7.92^{\star *}$ & 2.40 \\
\hline
\end{tabular}

${ }^{*}$ Main effect of cimaterol: $P<0.05 ;{ }^{* *}$ Main effect of oestradiol-17ß: $P<0.01$.

en $\mathrm{OE}$ (groups $U$ and $\mathrm{C}$ ). There was no significant effect of cimaterol treatment on LPL activity. Plasma urea, NEFA and serum triacylglycerols are shown in figure 1. Concentrations of plasma urea rose steadily throughout the experimental period and in treated animals were consistently lower than in the controls. However, treatment effects were variable. Comparison of orthogonal contrasts showed a significantly lower concentration due to a cimaterol effect on $\mathrm{d} 7(P<0.01), 14(P<0.01)$ and 21 $(P<0.001)$ and lower concentrations due to an oestradiol effect on d $28(P<0.05)$ and $42(P<0.01)$. Plasma NEFA concentrations fluctuated between $0.30-0.89$ $\mathrm{mmol} / \mathrm{l}$ and were lower in treated animals than in the control group. Treatment had no significant effect on plasma concentrations except for a reduction due to an oestradiol effect on d 7. Serum triacylglycerol concentrations showed no treatmentrelated change over the experimental period.

\section{DISCUSSION}

Previous reports have indicated variable in vivo effects of $\beta$-agonists on lipogenesis. Neither cimaterol nor oestradiol had any consistent effect on lipogenesis (table I). Coleman et al (1988) similarly reported that $\left[{ }^{14} \mathrm{C}\right]$-acetate incorporation into SCAT lipids was not affected in sheep given $2 \mathrm{mg}$ clenbuterol $/ \mathrm{kg}$ diet. Whereas a reduction in lipogenesis has been reported in SCAT from cattle fed $10 \mathrm{mg}$ clenbuterol/head/day (Miller et al, 1986) and in rat epididymal fat pad incubated with an unspecified concentration of clenbuterol (Duquette and Muir, 1985). Thornton et al (1985) reported markedly reduced rates of lipogenesis, stearate uptake and incorporation in subcutaneous ovine adipocytes incubated with $0.1 \mu \mathrm{g}$ clenbuterol. A similar though nonsignificant trend apparent for overall rates of lipogenesis was seen in SCAT (table I). In contrast, Hu et al (1988) reported stimulated rates of lipogenesis in growing lambs 

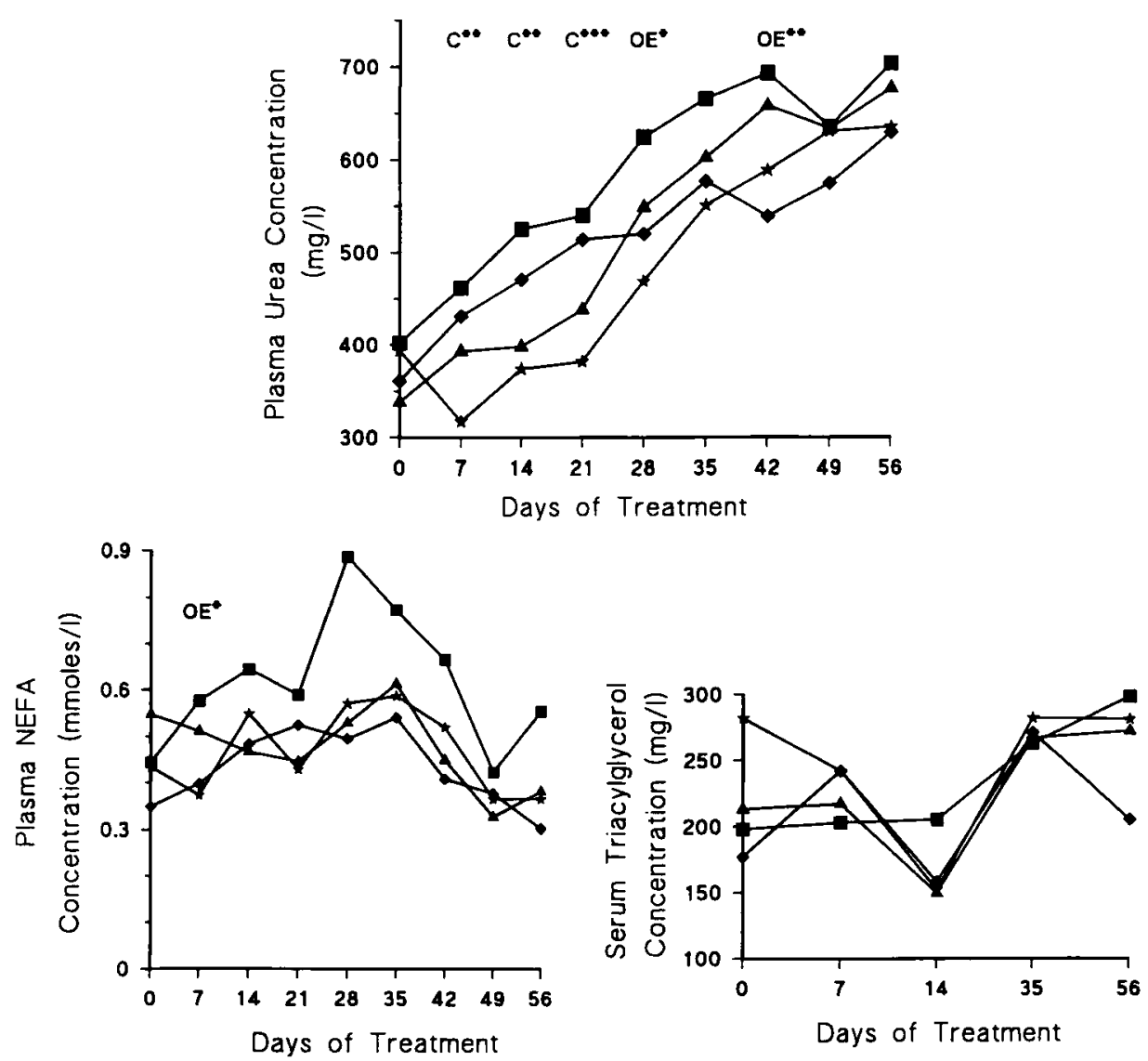

Fig 1. Concentration of plasma urea, NEFA and serum triacylglycerol through the treatment period. $\boldsymbol{\square}$ : group $U_{;} \Delta$ : group OE; $=$ group $C_{,} \star=$ group $O E+E$. Significance of the main effects of cimaterol and oestradiol- $17 \beta$ are shown by the letters $C$ and OE; $*=P<0.05, * *=P<0.01$, $* * \ldots * *=P<$ 0.001 .

fed clenbuterol. Coleman (1988) suggested that the inconsistent effects of clenbuterol on adipose tissue lipogenesis may indicate that its effect may be elicited via different mechanisms in sheep, cattle and rats. The same may also be true of cimaterol considering its similarity to clenbuterol both in structure and action on skeletal muscle. The effects of differences in tissue preparation and duration of exposure to hormonal preparations may also influence cellular response mediated via membrane receptors and may in part explain anomalies between in vivo and in vitro results.

There was no apparent effect of dietary cimaterol on in vitro lipolysis; however, when added to the incubation medium, cimaterol had a significant stimulatory effect on lipolysis (table II). The overall mean rates of lipolysis indicate that cimaterol $(1.5 \mu \mathrm{mol} / \mathrm{l})$ was a more potent stimulator of lipolysis than epinephrine $(2.7 \mu \mathrm{mol} / \mathrm{l})$. 
There was no additive effect of cimaterol and epinephrine; indeed, addition of cimaterol tended to decrease the rate of epinephrine-stimulated lipolysis. The lack of any sustained lipolytic response to dietary cimaterol was supported by the absence of any consistently significant change in plasma NEFA (fig 1). The improved carcass characteristics (less fat and greater protein deposition) reported by Galbraith et al (1990) suggests that at the dose level used the main effect in vivo of cimaterol was to promote a repartitioning of nutrients away from fat synthesis and deposition rather than increasing body fat mobilisation.

Although short-term exposure of cultured L6 muscle cells to isoproteranol, zinterol and salmefamol has been shown to increase cAMP concentrations (Pittman and Molinoff, 1983), a decrease in the number of $\beta$-adrenergic receptors following chronic exposure to clenbuterol has been noted in rat skeletal muscle by Rothwell et al (1987) and Kim and Sainz (1990) following cimaterol treatment. Such a decrease or down-regulation in receptor numbers may account for the fall in muscle cAMP concentrations. However, it is unclear why similar effects were not seen in the other tissues studied. The data suggest that the long-term effects of cimaterol in muscle tissue may not be fully mediated via a CAMPdependent process or indeed via a $\beta$ adrenergic receptor mechanism, a possibility suggested for clenbuterol by Reeds et al (1987).

The decrease in lipoprotein lipase activity in OE-treated animals is consistent with that reported in oestrogen-treated rat adipose tissue (Hamosh and Hamosh, 1975). Although cimaterol has been reported to increase lipoprotein lipase activity in rat skeletal muscle (Eadara et al, 1987), there was no evidence of any similar effect of cimaterol in adipose tissue.
Cimaterol has been previously been shown to cause a decrease in plasma urea concentration (Beermann et al, 1986 ; Galbraith et al, 1988). Similarly, MacVinish and Galbraith (1988) have reported a reduction in plasma urea levels in sheep following implantation with oestradiol-17 $\beta$ and trenbolone acetate. Several studies have reported elevated concentrations of plasma NEFA following administration of catecholamines or $\beta$-agonists (Basset, 1970; Beermann et al, 1985; Leenanuruska and McDowell, 1985). In the present study, blood samples were collected prior to feeding and the daily intake of cimaterol; thus any transient increase in NEFA would not have been detected. Scaife et al (1982) and Singh et al (1988) have reported little or no effect of a combined implant of oestradiol-17 $\beta$ and trenbolone acetate on plasma NEFA concentration, but marked changes in plasma triacylglycerol levels.

It would appear that cimaterol administered in the diet at $2 \mathrm{mg} / \mathrm{kg}$ had little effect on in vivo parameters of lipid metabolism. However, it did reduce the lipolytic response to cimaterol added in vitro and cyclic AMP concentrations in skeletal muscle. The effects of OE were confined to a reduction in lipoprotein lipase activity in SCAT. In general there were no significant interactions between the oestrogenic compound and cimaterol, nor evidence of similarity in the effects produced by the $2 \mathrm{com}$ pounds.

\section{ACKNOWLEDGMENTS}

The authors wish to thank $J$ Struthers, N Lokke and TW Begg for the care of the experimental animals and $C$ Jessiman, $G$ Wetherall and $M$ Franklin for advice on statistical methods and computing. 


\section{REFERENCES}

Baird J, Black NW, Faulkner DE (1967) Semiautomated method for the estimation of free fatty acids in plasma. J Clin Pathol 20, 905 . 909

Basset JM (1970) Metabolic effects of catecholamines in sheep. Aust J Biol Sci 23, 903-914

Beermann DH, Butler WR, Hogue DE, Dalrymple RH, Ricks CA (1985) Plasma metabolic hormone, glucose and free fatty acid concentrations in lambs fed the repartitioning agent cimaterol (CL263,780). J Anim Sci 61 (suppl 1), 255

Beermann DH, Reeds PJ, DeB Hovell FD, Kyle D (1986) Cimaterol elicits rapid physiological responses in growing lambs wholly nourished by intragastric infusion. $J$ Anim Sci 63 (suppl), 240

Buttery PJ, Dawson JM (1987) The mode of action of $\beta$-agonists as manipulators of carcass composition. In: Beta-Agonists and Their Effects on Animal Growth and Carcass Quality (Hanrahan JP, ed) Elsevier, London, 29-43

Coleman ME, Ereken PA, Smith SB (1988) Lipid synthesis and adipocyte growth in adipose tissue from sheep chronically fed a $\beta$ adrenergic agent. J Anim Sci 66, 372-378

Duquette PF, Muir LA (1985) Effect of the $\beta$ adrenergic agonists isoproteranol, clenbuterol, L-640,033 and BRL 35135 on lipolysis and lipogenesis in rat adipose tissue in vitro. $J$ Anim Sci 61 (suppl 1), 265

Eadara J, Dalrymple RH, Delay R, Ricks DA, Rosmos DR (1987) Cimaterol, a novel $\alpha$ agonist, selectively stimulates white adipose tissue lipolysis and skeletal muscle lipoprotein lipase activity in rats. Fed Proc 46, 1020

Galbraith H, Topps JH (1981) Effects of hormones on the growth and body composition of animals. Nutr Abstr Rev Ser B 51, 521540

Galbraith $H$, Scaife $J R$, Hatendi PR, Alderson EM, Watt DC, Stewart DC (1988) Effect of oestradiol- $17 \beta$ and cimaterol alone or combined on corticosteroid status and other endocrine and body characteristics of male castrate lambs. Proc Nutr Soc 47, 107A

Galbraith $\mathrm{H}$, Hatendi $\mathrm{P}$, Alderson EM, Scaife JR (1990) The effect of cimaterol and oestradiol$17 \beta$ alone or combined on growth and body composition of wether lambs. Anim Proc 5t, 311-319

Hamosh M, Hamosh P (1975) The effect of oestrogen on the lipoprotein lipase activity of rat adipose tissue. J Clin Inves 55, 1132-1135

Hu CY, Suryawan A, Forskeng NE, Dalrymple RH, Ricks CA (1988) Effect of cimaterol on sheep adipose tissue lipogenesis. Fed Proc 46, 1177

Kim YS, Sainz RD (1990) Characterisation of beta-adrenoreceptors in rat skeletal muscle. $J$ Anim Sci 68 (suppl 1), 251A

Krauss RM, Windmeuller HG, Levy RI, Fredrickson DS (1973) Selective measurement of two lipase activities in postheparin plasma of normal subjects and patients with hyperlipoproteinaemia. J Clin Invest 54, 1107-1124

Lawes Agricultural Trust (1977) Genstat V, Mark 4.01. Rothamsed Exptl Stat, Harpenden, Herts, UK

Leenanuruska D, McDowell GH (1985) Effects of prolonged intravenous infusion of adrenaline on glucose utilisation, plasma metabolites, hormones and milk production in lactating sheep. Aust J Biol Sci 38, 197-208

MacVinish LJ, Galbraith H (1988) The effect of implantation of trenbolone acetate and oestradiol-17 $\beta$ in wether lambs at two live weights on concentrations of steroidal residues and blood glucose, urea and thyroid hormones. Anim Prod 47, 75-85

Marsh WH, Fingerhut B, Miller H (1965) Automated and manual direct methods for the determination of blood urea. Clin Chem 11, 624-627

Miller MF, Garcia DK, Coleman ME, Ereken PA, Smith SB (1986) Nonesterified and glyceridefatty acid synthesis in bovine adipose tissue from heifers fed clenbuterol. J Anim Sci 63, (suppl 1), 236

Muir LA (1988) Effects of $\beta$-adrenergic agonists on growth and carcass characteristics of animals. In: Designing Foods: Animal Product Options in the Market Place. Natl Acad Press, Washington, DC, 184-193

Pittman RN, Molinoff PB (1983) Interactions of full and partial agonists with $\beta$-adrenergic receptors on intact L6 muscle cells. Mol Pharmacol 24, 398-408

Pothoven MA, Beitz DC (1973) Effect of adipose tissue. site, animal weight and long-term fast- 
ing on lipogenesis in the bovine. J Nutr 103 , 468-475

Pothoven MA, Beitz DC, Thornton JH (1975) Lipogenesis and lipolysis in adipose tissue of ad libitum and restricted fed cattle during growth. J Anim Sci 40, 957-962

Rao DR, Hawkins GE (1976) Activity of lipoprotein lipase in adipose tissue from steers. J Dairy Sci 59, 161-163

Reeds PJ, Hay SM, Dorwood PM, Palmer RH (1987) The effect of $\beta$-agonists and antagonists on muscle growth and body composition of young rats (Rattus sp). Comp Biochem Physiol 89C, 337-341

Reeds PJ, Mersmann HJ (1991) Protein and energy requirements of animals treated with $\beta$ adrenergic agonists: a discussion. $J$ Anim Sci $69,1532-1550$

Rothwell NJ, Stock MJ, Sudera DK (1987) Changes in tissue blood flow and $\beta$-receptor density of skeletal muscle in rats treated with the $\beta 2$-adrenoceptor agonist clenbuterol. $\mathrm{Br} J$ Pharmacol 90, 601-607
Scaife JR, Shehab-Eldin FM, Galbraith H (1982) The effect of subcutaneous implantation of trenbolone acetate and oestradiol-17 $\beta$ on plasma lipid concentrations in sheep. Hormon Metab Res 14, 589-592

Schotz MC, Garfinkle AS, Huebotter RT, Stewart JE (1970) A rapid assay for lipoprotein lipase. J Lipid Res 11, 68-69

Singh SB, Scaife JR, Galbraith H (1988) Blood and tissue lipid composition and lipase activity in wether lambs treated with trenbolone acetate combined with oestradiol-17 $\beta$ at two different live weights. Anim Prod 47, 87-96

Thornton RF, Tume RK, Payne G, Larsen TW, Johnson GW, Hohenhaus MA (1985) The influence of the 32 -adrenergic agonist, clenbuterol, on lipid metabolism and carcass composition in sheep. Proc $N Z$ Soc Anim Prod 45, 97-101

Trout DL, Estes EH, Freidberg SJ (1960) Titration of FFA in plasma: a study of current methods and a new modification. $J$ Lipid Res $1,199-202$ 